\title{
METHANE PRODUCTION AND BROMATOLOGICAL CHARACTERISTICS OF THE DIFFERENT FRACTIONS OF ORGANIC MUNICIPAL SOLID WASTE
}

\author{
Lorena Figueroa-Escamilla ${ }^{1}$, Simón González-Martínez ${ }^{1, *}$, Rosalinda Campuzano ${ }^{2}$ and \\ Idania Valdez-Vazquez ${ }^{3}$
}

\author{
${ }^{1}$ Environmental Engineering Department, Institute of Engineering, National University of Mexico (Universidad Nacional Autónoma de \\ México), 04510 Mexico City, Mexico \\ ${ }^{2}$ Biotechnology Department, Universidad Autónoma Metropolitana, Av. San Rafael Atlixco 186, Col. Vicentina, Iztapalapa, 09340 Mexico \\ City, Mexico \\ ${ }^{3}$ Unidad Académica Juriquilla, Institute of Engineering, National University of Mexico (Universidad Nacional Autónoma de México), Blvd. \\ Juriquilla 3001, 76230 Querétaro, Mexico
}

Article Info:

Received:

26 February 2021

Revised:

26 April 2021

Accepted:

17 May 2021

Available online:

30 June 2021

Keywords:

Anaerobic digestion

Methane production

Bromatological determinations;

Organic fraction of municipal solid

waste

\section{ABSTRACT}

In some countries, garden trimmings are not considered part of urban solid wastes. Lignocellulosic substances contribute to heterogeneity, complicating the analysis of the organic fraction of municipal solid waste (OFMSW) and, subsequently, for methane production. Some of the substances contained in OFMSW are readily biodegradable, and others are not. This work analyses OFMSW from Mexico City and the methane production from its separate components. From OFMSW, nine fractions were visually identified and separated. Including bromatological and fibre analysis, the characterisation of OFMSW and its components was made to determine how the different substances influence methane production. Together, branches, dry leaves, fresh garden trimmings, unsorted wastes (mainly garden trimmings), kitchen paper, and waste vegetables represent $56 \%$ of OFMSW in weight. Fruit waste and unsorted organics contribute to $60 \%$ of the total methane production. Except for branches and dry leaves, methane production increases inversely with the content of lignocellulosic compounds. Animal waste, having the highest concentrations of proteins and lipids and the lowest in lignocellulosic substances, is characterised by the highest level of methane production. Fibre-rich fractions in OFMSW contributed with little or no methane production. Higher concentrations of lignocellulosic substances in the fractions resulted in lower methane production rates.

\section{INTRODUCTION}

By 2050, the world is expected to increase waste generation by 70 percent, from 2.01 billion tonnes of waste in 2016 to 3.40 billion tonnes of waste annually (Hoornweg et al., 2013). Individuals and governments make decisions about waste management that affect the daily health and cleanliness of communities. Increasing waste trends are particularly intense in less developed countries (Kaza et al., 2018). Waste production trends not only increase resource stress but also contribute to greenhouse gases. A transformation toward resource-circular systems and sustainable municipal solid waste management is necessary (Wainaina et al., 2019). Growing environmental pressure has caused regional/national targets to divert waste from landfills and increase the recycling and recovery rate. While developed countries struggle to reach a zero MSW produc- tion through recycling, developing countries struggle to avoid open dumpsites by implementing controlled landfill sites (Kumar et al., 2019; Manjunathaa et al., 2019).

A preferred treatment method for the organic fraction of municipal solid waste (OFMSW) is anaerobic digestion (AD) because it allows the production of methane as fuel, and the resulting solids (digestate) can be used for soil improvement (Möller and Müller, 2012). The whole AD microbial degradation process is divided into four consecutive biological processes: 1) the hydrolysis of complex organic molecules to soluble monomers takes place in the first step; 2) acidogenesis or fermentation is the process by which the soluble monomers from hydrolysis are converted to alcohols, volatile fatty acids (VFA), namely acetic, propionic and butyric acids, and $\mathrm{CO}_{2}$ and hydrogen; 3 ) acetogenesis is the step where several of the previously email: sgm@pumas.ii.unam.mx 
produced VFA and alcohols are converted into acetate, which is an essential molecule used by methanogens as substrate and 4) methanogenesis is the final step where different archaea can use acetate, $\mathrm{CO}_{2}$ and hydrogen to produce methane as a final product (Bajpai, 2017).

Methane from the organic fraction of the municipal solid wastes (OFMSW) is a potential energy source. Results from several studies indicate that biogas produced by microbial activity does not contain only $\mathrm{CO}_{2}$ and $\mathrm{CH}_{4}$, but also other compounds that need consideration when using this biogas as fuel to generate electricity (Rasi et al., 2006). Papurello (2019) demonstrates efficient biogas sampling procedures and precise analytical methods. Several undesired compounds need to be removed from biogas before using it as fuel. There are several standard processes to remove $\mathrm{CO}_{2}$, hydrogen sulphide, and other sulphur compounds from biogas, but special attention needs to be paid to organic silicon compounds that cause abrasion in the engines (Ohannessian et al., 2008).

OFMSW heterogeneity (Naroznova et al., 2016) and complex composition (VALORGAS, 2010) are limiting factors of OFMSW for biogas production. Methane potential depends on substrate characteristics and biodegradability (Campuzano and González-Martínez, 2016). According to reports from VALORGAS (2010), Kobayashi et al. (2012), Naroznova et al. (2016), and Alibardi and Cossu (2016), the knowledge of OFMSW composition and characteristics allows the improvement of urban solids waste management and subsequent methane production. Eventually, it is possible to determine which fractions or components can be considered for methane production and which ones need to be avoided during source separation. According to the classifications in different countries, the contents of fiber-rich substances can significantly vary. For example, kitchen paper and garden trimmings are accepted as organic waste in countries like the United Kingdom, Finland, and Denmark. Still, they are not allowed in other countries like Norway and Sweden (Naroznova et al., 2016).

Geographic and socioeconomic aspects affect OFMSW composition (VALORGAS, 2010). Studies have been performed to determine how much methane or hydrogen can be produced according to the bromatological and chemical characteristics of the different OFMSW fractions (Kobayashi et al., 2012; Alibardi and Cossu, 2016; Naroznova et al., 2016; Edwiges et al., 2018). Every study classifies OFMSW according to their specific objectives, and there are essential differences between selected components. In Japan, Kobayashi et al. (2012) analyzed Kyoto OFMSW, and they found, in kitchen wastes, animal rests, vegetables, paper, cereals, food wrappings, tea and coffee bags, and some garden trimmings. In Italy, in an anaerobic digestion plant, Alibardi and Cossu (2016) found meat, fish, cheese, fruits, vegetables, pasta, bread, and some unidentifiable substances. In Denmark, Naroznova et al. (2016) characterized OFMSW in the city of Halsnæs. They classified the fractions as animal food waste, vegetable food waste, kitchen paper, vegetation waste, molded fibers, animal straw, dirty paper, and dirty cardboard.

Using bromatological and physicochemical analysis, several authors found that OFMSW fractions have different influences on methane production during anaerobic digestion. One concern about fiber-rich compounds in OFMSW are lignocellulosic compounds and their relative concentration of cellulose, hemicellulose, and lignin (Teghammar et al., 2010, Triolo et al., 2011). Edwiges et al. (2018) found that the biochemical methane potential (BMP) improved when the wastes contained higher amounts of lipids while lignin negatively affected methane production. Xu et al. (2014) also noted that methane production was negatively affected when the substrate was lignin-rich. Extractable substances, such as cellulose and other compounds, are desirable because they have a positive effect on methane production. Labatut et al. (2011) observed that the highest methane productions were from substrates rich in fat and carbohydrates and that the lowest rates were obtained with lignocellulosic-rich substances.

Lignocellulosic biomass is the most important and more abundant product from photosynthesis. In vegetal biomass, hydrogen bridges, forming microfibers with hemicellulose and covered by lignin compounds (Taherzadeh and Karimi, 2008), bind cellulose chains. Hemicellulose is the essential union between lignin and cellulose fibers, providing rigidity to the cellulose-hemicellulose-lignin compounds, resulting in highly recalcitrant compounds (Hendriks and Zeeman, 2009). High fiber concentrations in organic wastes indicate low biodegradability, and lignin presence is undesired during methane production in anaerobic digestion (Alibardi and Cossu, 2016; Fonoll et al., 2016). According to Campuzano and González-Martínez (2016), lignocellulosic compounds represent approximately $40 \%$ in weight in Mexico City's OFMSW, meaning that every kilogram of OFMSW contains $225 \mathrm{gVS} / \mathrm{kg}$, and, from them, only $135 \mathrm{~g}$ are biodegradable. The remaining $90 \mathrm{~g}$ are slowly biodegradable or not susceptible to transformation to biogas; the authors did not mention which components contain higher amounts of lignocellulosic compounds.

Even though OFMSW is a potential source of bioenergy, it is crucial to determine how its composition affects the anaerobic digestion process. Independently of the specific local legislation, there will always be different substances in OFMSW. Paper and cardboard are generally present and also are cellulose-rich compounds (Kobayashi et al., 2012; Naroznova et al., 2016; González-Miranda et al., 2016). Fruits and vegetables are cellulose and fiber-rich substances and represent almost $74 \%$ of OFMSW (Nielfa et al., 2015; Naroznova et al., 2016; Edwiges et al., 2018). Animal rests are present in OFMSW in lower quantities and are not fiber-rich (Kobayashi et al., 2012; Naroznova et al., 2016).

Considering the discrepancies observed in other published research about OFMSW classification, this work aims to determine the influence of different compounds in the identifiable OFMSW fractions on methane production. For this purpose, it was necessary to identify and quantify OFMSW components according to their physicochemical and chemical characteristics.

\section{MATERIALS AND METHODS}

OFMSW from Mexico City was used for this purpose, considering that garden trimmings and market wastes are allowed as part of OFMSW.

\subsection{OFMSW sampling and classification}

OFMSW sampling and conservation was made on one 
day when source-sorted organic wastes are collected. Considering that between 380 and 450 trucks discharge solid wastes every day in the Coyoacán transfer station, eleven trucks were randomly selected and, from each one, approximately $100 \mathrm{~kg}$ were separated and thoroughly mixed; from the resulting amount, $200 \mathrm{~kg}$ were set apart according to the quartering method (ASTM D5231-92, 2016). Inorganic materials and plastics were hand-separated and discarded. The sample was distributed in 2-liter freezing bags, and they were immediately frozen at $-20^{\circ} \mathrm{C}$.

In the laboratory, approximately $20 \mathrm{~kg}$ of slowly defrosted OFMSW were placed in trays, and, carefully, all components were visually identified, manually separated, and grouped according to their apparent origin. To homogenize the separated and identified fractions before analysis, they were ground using a $0.35 \mathrm{~W}$ electric disc mill (DelRey, Mexico).

\subsection{Biochemical methane potential tests}

For biochemical methane production (BMP), an AMPTS II system from Bioprocess Control AB (Sweden) was used. The inoculum was anaerobic granular sludge from the wastewater treatment plant of a large beer factory in Mexico City. The granular sludge was washed three times using tap water and concentrating it using a centrifuge to separate exogenous dissolved substances from the solids. For BMP, VDI 4630 recommendations were followed: Inoculum to substrate ratio (ISR, as volatile solids) was 4:1; temperature, $35^{\circ} \mathrm{C}$ and per triplicate (VDI 4630, 2016). According to experiences from previous projects, the duration of the tests was set to 21 days (Campuzano and González-Martínez, 2015). Biogas sampling and analysis were performed daily. A blank only with inoculum was used as a reference (blank).

The theoretical biochemical methane production (TBMP) is widely used to estimate methane potential. Triolo et al. (2011) calculated TBMP after modifying the method proposed by Møller et al. (2004), where they included lignin with the following empirical formula, $\mathrm{C}_{10} \mathrm{H}_{13} \mathrm{O}_{3}$, and with it, they calculated the TBMP of lignin through the Symons and Buswell (1933) equation resulting in a value of $727.1 \mathrm{NLCH}_{4} / \mathrm{kglignin}$. Triolo et al. (2011) propose Equation 1 to calculate TBMP. Equation 1 includes lipids $\left(\mathrm{C}_{57} \mathrm{H}_{104} \mathrm{O}_{6}\right)$, protein $\left(\mathrm{C}_{5} \mathrm{H}_{7} \mathrm{O}_{2} \mathrm{~N}\right)$, carbohydrates $\left(\mathrm{C}_{6} \mathrm{H}_{10} \mathrm{O}_{5}\right)$, and lignin $\left(\mathrm{C}_{10} \mathrm{H}_{13} \mathrm{O}_{3}\right)$; values expressed as $\mathrm{g} / \mathrm{kgVS}$.
$T B M P=\left(C_{57} H_{104} \mathrm{O}_{6} \cdot 1014+\mathrm{C}_{5} \mathrm{H}_{7} \mathrm{O}_{2} \mathrm{~N} \cdot 496+\mathrm{C}_{6} \mathrm{H}_{10} \mathrm{O}_{5} \cdot 415+\mathrm{C}_{10} \mathrm{H}_{1}\right.$ ${ }_{3} \mathrm{O}_{3} \cdot 727 \cdot 0.001$

TBMP is used to evaluate the biodegradability of a substrate using Equation 2 (Triolo et al., 2011).

Anaerobic biodegradability $=B M P / T B M P \cdot 100 \%$

\subsection{Analytical methods}

The different fractions and original OFMSW were analysed for humidity, total solids (TS), volatile solids (VS), chemical oxygen demand (COD), Kjeldahl nitrogen (KN), ammonia nitrogen (NH4-N), total phosphorus (TP), and $\mathrm{pH}$. These determinations were performed according to APHA (2005). Protein, grease and fats, total carbohydrates, lignin, cellulose, and hemicellulose were determined according to Van Soest (Van Soest, 1963, Goering and Van Soest, 1970) and Official Methods of Analysis of AOAC International (AOAC, 2012). Biogas composition was determined using an SRI 8610c gas chromatograph equipped with a thermal conductivity detector and stainless steel silica gel packed column $8600-P K 1 \mathrm{~A}$ using helium gas as carrier at a flow rate of $27 \mathrm{~mL} / \mathrm{min}$.

For carbohydrates fractioning, the method proposed by the Cornell Net Carbohydrate and Protein System (CNCPS) was used. This method separates the fractions according to their degradability. Structural carbohydrates were calculated as the difference between neutral detergent fibre and non-soluble protein. Non-fibrous carbohydrates or non-structural carbohydrates are the difference between total carbohydrates and structural carbohydrates (Sniffen et al., 1992, Lanzas et al., 2007).

\section{RESULTS AND DISCUSSION}

Approximately $20 \mathrm{~kg}$ OFMSW were overnight defrosted at $4^{\circ} \mathrm{C}$. The visually identified fractions were: Food waste from animal origin (animal waste), flour products, fruits, vegetables, kitchen paper, dry leaves, branches (garden cuts), fresh trimmings, and a fraction was called unsorted as these wastes could not be visually identified or separated but mainly were related to garden trimmings and dry leaves. Table 1 shows a description of the substances found in every fraction; Figure 1 shows the fractions' images.

TABLE 1: Identified components in OFMSW.

\begin{tabular}{|c|c|c|}
\hline Fraction & $\%$ OFMSW & Visually identified components \\
\hline Fruits & 36 & $\begin{array}{l}\text { Rests, peelings, and seeds from oranges, lemon, pineapple, watermelon, bananas, papaya, mamey (Pouteria sapota), } \\
\text { mango, and avocado peeling and seeds, grapes, and tamarind shells and seeds }\end{array}$ \\
\hline Vegetables & 13 & $\begin{array}{l}\text { Jicama, carrots, different types of chilies, peanuts, potato peeling and rests, red beet, peas, fresh corn grains, garlic, on- } \\
\text { ions, and seeds from sunflower }\end{array}$ \\
\hline Animal waste & 8 & Red and white eggshells, beef leftovers and bones, chicken skin and bones \\
\hline Flour products & 3 & Tortilla (typical Mexican flatbread from maize) \\
\hline Fresh trimmings & 6 & Bugamvilia, fresh grass, pine needles, eucalyptus, palm, and ash tree leaves \\
\hline Dry leaves & 7 & Leaves from different unidentified trees and maize leaves. \\
\hline Branches & 4 & Different unidentified small and thin tree branches (from trimmings) \\
\hline Kitchen paper & 2 & Paper napkins, kitchen paper, and some wax paper \\
\hline Unsorted & 21 & Mostly from dry leaves and trimmings, in small pieces, unidentified \\
\hline
\end{tabular}




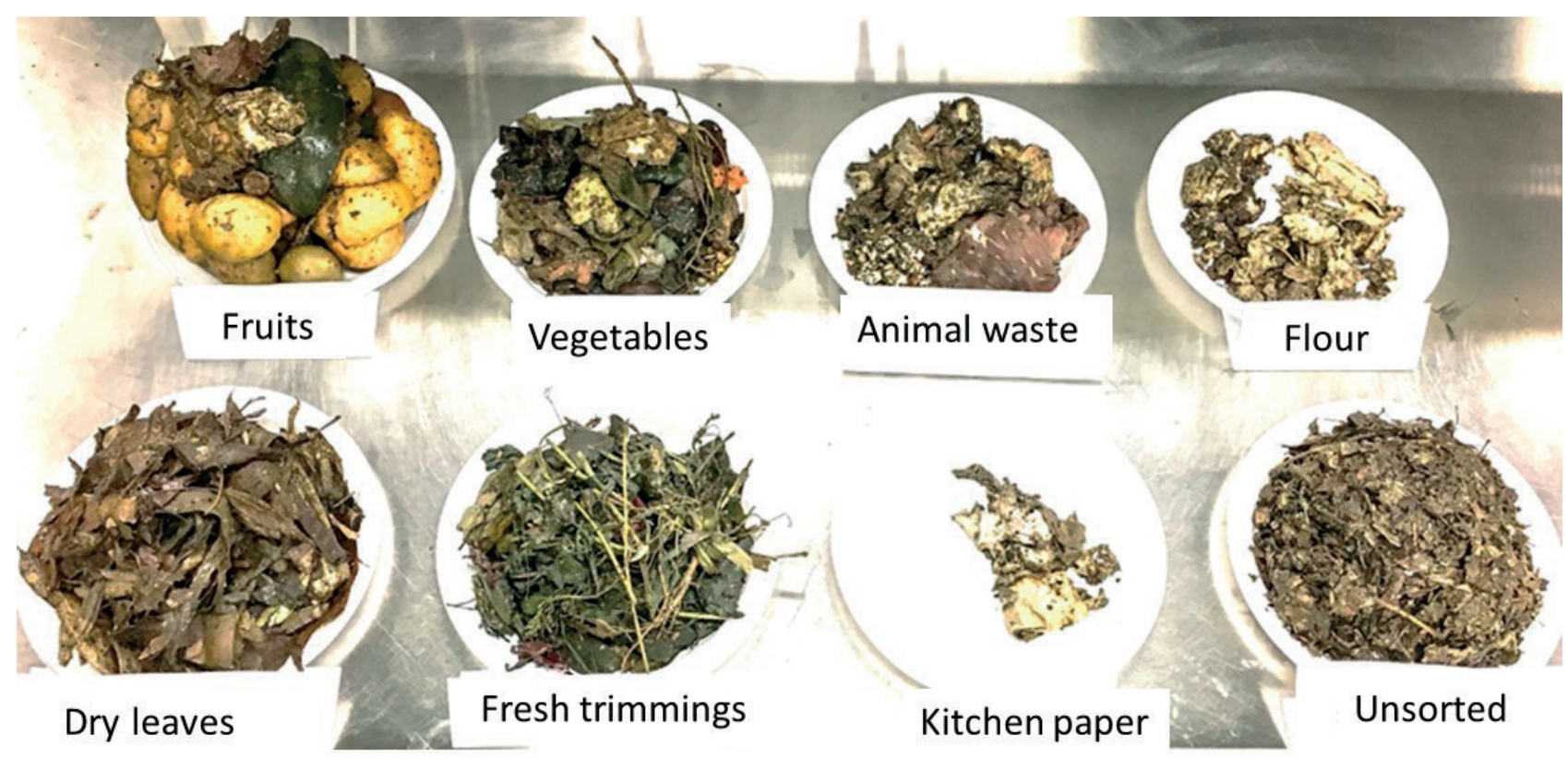

FIGURE 1: The identified OFMSW fractions (branches are not shown).

\subsection{Characterisation of OFMSW fractions}

\subsubsection{OFMSW fractions}

The fraction with the highest weight percentage is fruits $(36 \%)$ followed by unsorted $(21 \%)$ and then vegetables (13\%) (Table 1). The fractions with the lowest contribution in OFMSW are kitchen paper (2\%) and cereal waste (3\%). Considering unsorted, dry leaves, garden trimmings, and branches together, garden wastes amount to $37 \%$ in weight; this last value is significant compared to reports from other countries (Naroznova et al., 2016; Kobayashi et al., 2016).

Vegetables, fruits, and fresh trimmings present the lowest solids concentrations with values from 22 to $28 \%$. In comparison, the fractions with the highest solids concentrations are branches with $55 \%$, followed by animal wastes and flour products with 45 and $44 \%$, respectively (compare humidity in Table 2). When comparing these results with the ones Naroznova et al. (2016) found in Denmark, similarities can be found: they report $24 \%$ for vegetables and, in this research, 23 and $22 \%$ were determined for fruits and vegetables, respectively. For wastes from animal origin, Naroznova et al. (2016) report $41 \%$ solids concentration and $45 \%$ are observed in this research.

The fraction with the lowest VS corresponds to vegetables with $192 \mathrm{~g} / \mathrm{kg}$ and the highest to branches with $475 \mathrm{~g} /$ $\mathrm{kg}$. Naroznova et al. (2016) report values similar to the ones in this research: food animal wastes, $344 \mathrm{~g} / \mathrm{kg}$, vegetables, $223 \mathrm{~g} / \mathrm{kg}$, and vegetation wastes (garden trimmings), $240 \mathrm{~g} / \mathrm{kg}$; in the case of kitchen paper, they report $491 \mathrm{~g} /$ $\mathrm{kg}$ compared to $265 \mathrm{~g} / \mathrm{kg}$ in this work. The VS/TS ratio is an indicator of the organic material concentration related to total solids: The highest VS/TS ratio belongs to fruits with 0.9 , followed by cereals with 0.87 , branches, 0.86 , and kitchen paper, 0.86; the lowest value is for animal wastes

TABLE 2: Characterization of OFMSW fractions.

\begin{tabular}{|c|c|c|c|c|c|c|c|c|c|}
\hline & ${ }^{3}$ Humidity\% & VS/TS & ${ }^{3}$ VS & ${ }^{3}$ Protein & ${ }^{2}$ Lipids & $\begin{array}{c}{ }^{3} \text { Total } \\
\text { Carbohydrates }\end{array}$ & Hemicellulose* & Cellulose* & Lignin* \\
\hline & & & & \multicolumn{6}{|c|}{$\mathrm{g} / \mathrm{kg}_{\mathrm{vs}}$} \\
\hline Animal & $55 \pm 0.6$ & 0.70 & $320 \pm 2.6$ & $373 \pm 45.6$ & $390-396$ & $70 \pm 7.5$ & 3 & 4 & 39 \\
\hline Kitchen paper & $69 \pm 0.1$ & 0.86 & $265 \pm 1.3$ & $62 \pm 2.4$ & $202-204$ & $970 \pm 44.3$ & 20 & 207 & 32 \\
\hline Flour & $56 \pm 0.4$ & 0.87 & $380 \pm 3.5$ & $123 \pm 5.3$ & 119-122 & $406 \pm 16.1$ & 232 & 53 & 32 \\
\hline Vegetables & $78 \pm 0.4$ & 0.84 & $192 \pm 2.8$ & $121 \pm 5.5$ & $95-97$ & $464 \pm 25.8$ & 63 & 102 & 65 \\
\hline Fruits & $77 \pm 0.2$ & 0.90 & $206 \pm 4.3$ & $94 \pm 3.0$ & $78-83$ & $505 \pm 12.2$ & 7 & 121 & 32 \\
\hline Branches & $45 \pm 0.1$ & 0.86 & $475 \pm 4.9$ & $44 \pm 2.3$ & $93-100$ & $451 \pm 14.5$ & 155 & 37 & 401 \\
\hline Fresh trimmings & $72 \pm 0.2$ & 0.81 & $227 \pm 1.6$ & $130 \pm 9.3$ & $147-155$ & $504 \pm 12.2$ & 51 & 111 & 69 \\
\hline Dry leaves & $64 \pm 0.2$ & 0.84 & $306 \pm 2.4$ & $89 \pm 5.9$ & $156-176$ & $394 \pm 13.6$ & 49 & 98 & 68 \\
\hline Unsorted & ${ }^{5} 66 \pm 0.5$ & 0.73 & ${ }^{5} 252 \pm 4.0$ & $131 \pm 4.3$ & $170-189$ & $294 \pm 18.6$ & 62 & 33 & 165 \\
\hline OFMSW & ${ }^{5} 71 \pm 1.1$ & 0.78 & ${ }^{5} 228 \pm 3.0$ & $168 \pm 4.7$ & 133-136 & $791 \pm 41.3$ & 9 & 102 & 53 \\
\hline
\end{tabular}

\footnotetext{
${ }^{3}$ Three replicas; ${ }^{5}$ Five replicas; ${ }^{2}$ In lipids only two replicas were made; both values are reported. *Average of three replicas; no standard deviations are available.
} 
with 0.7 , containing eggshells and bones, and unsorted materials with 0.73. Campuzano and González-Martínez (2016) report a VS/TS ratio of 0.75 for other OFMSW samples in Mexico City; VS/TS of the OFMSW sample taken for this research is 0.78 .

From Table 1 and Figure 2, the following observations can be drawn:

- Wastes of animal origin is the fraction with the lowest concentration of lignocellulosic substances (46 g/ $\mathrm{kgVS}$ ) and the highest in fat and protein.

- Fruits have the third-highest concentration of carbohydrates; fat and protein concentrations are relatively low. The concentration of lignocellulosic compounds is low but, with $160 \mathrm{~g} / \mathrm{kgVS}$, it is three times higher than the amounts in wastes of animal origin.

- Dry leaves contain high hemicellulose and lignin concentrations with 49 and $68 \mathrm{~g} / \mathrm{kgVS}$, respectively. Confusing can be that fat concentration is relatively high in dry leaves; it needs to be considered that the maize leaves found in OFMSW are disposed of after being used to wrap a traditional meal called tamales (fatty).

- Vegetables present higher concentrations in protein with $121 \mathrm{~g} / \mathrm{kgVS}$, and the concentration of degradable carbohydrates is higher than the average among the fractions with $299 \mathrm{~g} / \mathrm{kgVS}$. This fraction reports lower lignin concentrations than dry leaves but higher in cellulose and hemicellulose with 102 and $63 \mathrm{~g} / \mathrm{kgVS}$, respectively.

- Fresh trimmings, as expected, have higher cellulose and lignin concentrations with 111 and $69 \mathrm{~g} / \mathrm{kgVS}$, respectively. Nevertheless, it presents lower hemicellulose concentrations and is the third in protein concentration. The relatively high lipids concentration suggests that this fraction was previously in contact with other fat-rich materials.
- Kitchen paper has the highest cellulose concentration with $207 \mathrm{~g} / \mathrm{kgVS}$ and the lowest lignin concentration with $32 \mathrm{~g} / \mathrm{kgVS}$; it also has the highest degradable carbohydrates concentration and the second place in lipids with $203 \mathrm{~g} / \mathrm{kgVS}$.

- Unsorted materials have third place in lipids and protein concentrations and one of the highest lignocellulose concentrations. Lignin is the second highest with $165 \mathrm{~g} / \mathrm{kgVS}$ and, after animal rests, the lowest in degradable carbohydrates.

- Flour-rich substances present higher lignocellulosic concentrations, being hemicellulose the highest with $232 \mathrm{~g} / \mathrm{kgVS}$. Protein, lipids, and degradable carbohydrates are 123,121 , and $121 \mathrm{~g} / \mathrm{kgVS}$, respectively. As no amylase was used to determine the fiber, starch could not be avoided. Most probably, the starch interferes with the determination, and hemicellulose reports slightly higher values than expected.

- Of all fractions, branches have the highest lignocellulose concentrations with $401 \mathrm{~g} / \mathrm{kgVS}$. It has the lowest concentrations of protein and lipids and relatively high concentrations of degradable carbohydrates.

- OFMSW can be considered as a general average value of all determinations shown in Table 2.

The general characteristics of Mexico City's OFMSW are similar to the organic solid wastes from other countries. Table 3 shows a comparison of the OFMSW characteristics found in several papers with the ones reported in this research. Grinsted, Prague, Lisbon, and Padua report TS above $300 \mathrm{~g} / \mathrm{kg}$; under $300 \mathrm{~g} / \mathrm{kg}$ are Mexico City, Verona, Copenhagen, and Southampton. Other cities like Cadiz, Kerala, Canton and Beirut, report values under $200 \mathrm{~g} / \mathrm{kg}$. Similar values can be found for VS in these same cities. The VS/TS value reported in this research is 0.78 , which is

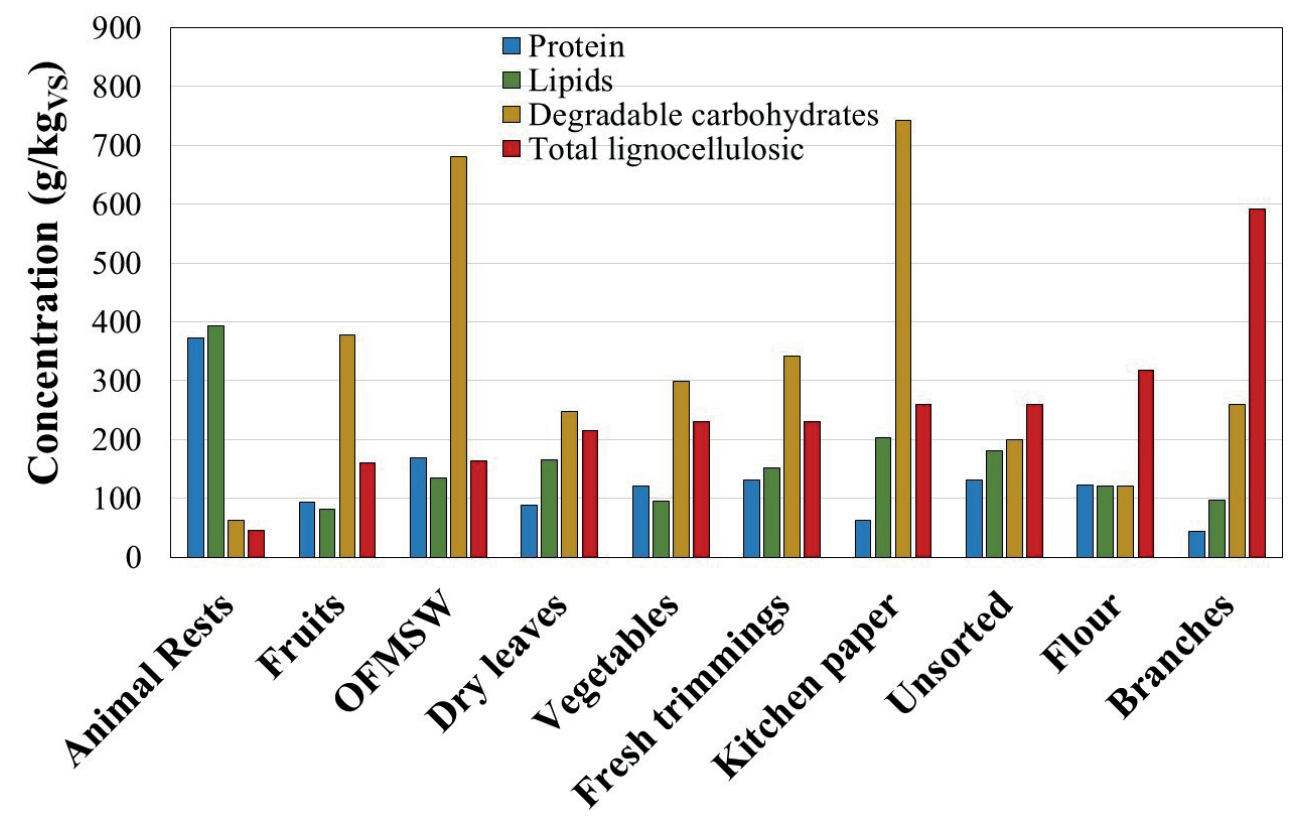

FIGURE 2: Comparison of bromatological characteristics in the separated fractions. The fractions are organized in ascending concentration of total lignocellulosic substances. 
TABLE 3: Comparison of the OFMSW characteristics of this research with other countries. All values are wet based (raw OFMSW)

\begin{tabular}{|c|c|c|c|c|c|c|c|}
\hline City & $\begin{array}{l}\mathrm{TS} \\
\mathrm{g} / \mathrm{kg}\end{array}$ & $\begin{array}{l}\text { VS } \\
\mathbf{g} / \mathbf{k g}\end{array}$ & $\begin{array}{c}\text { VS/TS } \\
-\end{array}$ & $\begin{array}{l}\mathrm{KN} \\
\mathrm{g} / \mathrm{kg}\end{array}$ & $\begin{array}{l}\mathrm{TP} \\
\mathbf{g} / \mathbf{k g}\end{array}$ & $\begin{array}{l}\text { COD } \\
\mathbf{g} / \mathbf{k g}\end{array}$ & Reference \\
\hline Kerala, India & 187 & 169 & 0.91 & 1.04 & - & - & Sajeena Beevi et al., 2015 \\
\hline Padua, Italy & 305 & 281 & 0.92 & 7.7 & 1.16 & 575 & Alibardi y Cossu, 2015 \\
\hline Verona, Italy & 288 & 228 & 0.79 & 28 & 2.4 & 347 & Bolzonella et al., 2005 \\
\hline Lisbon, Portugal & 338 & 276 & 0.82 & 5.1 & 1.7 & - & VALORGAS, 2010 \\
\hline Luton, UK & 237 & 218 & 0.91 & 7.4 & 1.2 & - & VALORGAS, 2010 \\
\hline Southampton, UK & 277 & 244 & 0.88 & 8.9 & 1.9 & - & Banks et al., 2011 \\
\hline Beirut, Lebanon & 186 & 172 & 0.93 & - & 0.7 & - & Ghanimeh et al., 2012 \\
\hline Prague, Chech Republic & 325 & 231 & 0.71 & 4.5 & 0.7 & - & Hanc et al., 2011 \\
\hline Cadiz, Spain & 172 & 74 & 0.43 & 26.0 & - & 140 & Forster-Carneiro et al., 2008b \\
\hline Canton, China & 184 & 113 & 0.62 & 4.2 & 0.4 & - & Dong et al., 2010 \\
\hline Karlsruhe, Germany & 255 & 225 & 0.88 & 7.8 & - & 350 & Nayono et al., 2009 \\
\hline Copenhagen, Denmark & 283 & 250 & 0.88 & 7.4 & 1.4 & - & Davidsson et al., 2007 \\
\hline Grindsted, Denmark & 356 & 307 & 0.86 & 6.3 & - & 431 & Hartmann and Ahring, 2006 \\
\hline Mexico City, Mexico & 297 & 223 & 0.75 & 5.4 & 1.8 & 304 & $\begin{array}{l}\text { Campuzano and } \\
\text { González-Martínez, } 2015\end{array}$ \\
\hline This research & 290 & 228 & 0.78 & 6.1 & 3.9 & 294 & \\
\hline
\end{tabular}

slightly lower than most of the values reported for other cities; the lowest VS/TS values of 0.43 and 0.42 correspond to Cadiz and Canton. Important differences are observed in macronutrients: $\mathrm{KN}$ presents values between 1.04 and $28 \mathrm{~g} / \mathrm{kg}$ for Kerala and Verona, respectively. Grindsted, Copenhagen, Karlsruhe Luton, Lisbon, and Padua report similar $\mathrm{KN}$ to this research. TP values vary between $0.4 \mathrm{~g} / \mathrm{kg}$ in Canton to $2.4 \mathrm{~g} / \mathrm{kg}$ in Verona, and, surprisingly, this research reports $3.9 \mathrm{~g} / \mathrm{kg}$ TP, the highest of all values. Table 3 shows that fruits, vegetables, and fresh trimmings contain elevated phosphorus concentrations. Except for Cadiz, other cities present higher COD values than the one from this research. No explanation can be offered about how COD can be related to TS because the reported values in Table 3 do not show any correlation.

\subsubsection{Bromatological characteristics}

According to the characteristics of the substances identified in the fractions, the following observations can be made.

Protein. As expected, animal wastes present the highest protein concentration with $373 \mathrm{~g} / \mathrm{kgVS}$ and branches and paper, the lowest with 44 and $62 \mathrm{~g} / \mathrm{kgVS}$, respectively. The highest values agree with the ones reported by Kobayashi et al. (2012) for kitchen wastes and wasted animal rests. Alibardi and Cossu (2016) report higher concentrations for meat, fish, and cheese rest. Edwiges et al. (2018) report similar values as those in this work for protein in fruits and vegetables of $15.9 \%$ VS. Campuzano and González-Martínez (2016) report a total value of $152 \mathrm{~g} / \mathrm{kgVS}$ for OFMSW, like the one in this research of $168 \mathrm{~g} / \mathrm{kgVS}$. From the total protein in OFMSW, animal wastes contribute with the highest value of $27 \%$, and the lowest is for paper with less than $1 \%$ (Figure 2).

Lipids. Like protein concentration, animal wastes present the highest value with $393 \mathrm{~g} / \mathrm{kgVS}$; the lowest value is for fruits with $81 \mathrm{~g} / \mathrm{kgVS}$. Kobayashi et al. (2012) report similar results, and Alibardi and Cossu (2016) report similar results for fish, meat, and cheese wastes. For Brazil, Edwiges et al. (2018) report an average value of $4.5 \% \mathrm{VS}$ for fruits and vegetables. From the total grease and oil in OFMSW, the highest concentration is for unsorted wastes with $25 \% \mathrm{VS}$ and the lowest for paper with less than 2\%VS (Figure 2).

Carbohydrates. Table 2 shows that the highest carbohydrate concentration is for paper with $970 \mathrm{~g} / \mathrm{kgVS}$. Coinciding with this work, Kobayashi et al. (2012) report 959 g/kgVS for wrapping paper. Alibardi and Cossu (2016), González-Miranda et al. (2016), and this work report that the lowest value for carbohydrates is for animal rests. Campuzano and González-Martínez (2016) report $529 \mathrm{~g} /$ kgVS for OFMSW, while this research determined a higher value with $791 \mathrm{~g} / \mathrm{kgVS}$. As a percentage of OFMSW, fruits correspond to $41 \%$ of the total carbohydrates, and animal wastes are the lowest with $2 \%$.

Cellulose. Table 2 shows that kitchen paper has the highest cellulose concentration with $207 \mathrm{~g} / \mathrm{kgVS}$, followed by fruits with $121 \mathrm{~g} / \mathrm{kgVS}$. Kobayashi et al. (2012) and González-Miranda et al. (2016) show that paper also contains the highest cellulose concentration and Naroznova et al. (2016) indicate dirty carton with the highest cellulose followed by moulded fibres and fruits and vegetables with $120 \mathrm{~g} / \mathrm{kgVS}$. Kobayashi et al. (2012) report lower cellulose contents in wastes from animal origin with 1.6 $\mathrm{g} / \mathrm{kgVS}$, and Naroznova et al. (2016) also note lower cellulose content in waste animal origin with $2 \% \mathrm{VS}$. Edwiges et al. (2018) report average cellulose values in fruits and vegetables of $17.1 \% \mathrm{VS}$; in this research, the average cellulose concentrations in fruits and vegetables are 12.1 and $10.2 \%$ VS, respectively; from the total cellulose concentration in OFMSW, fruits contribute with $50 \%$ and wastes from animal origin with less than $1 \%$.

Hemicellulose. Like cellulose, wastes from animal or- 
igin present the lowest concentration with $3 \mathrm{~g} / \mathrm{kgVS}$. In contrast, Kobayashi et al. (2012) found that "other kitchen wastes" have $2.7 \%$ VS and Naroznova et al. (2016) found $3 \%$ VS hemicellulose in dirty paper. González-Miranda et al. (2016) report similar values to those in this work for fruits with $1 \% \mathrm{VS}$. (10 g/kgVS). This work's highest values for hemicellulose are for flour (cereals) with $232 \mathrm{~g} / \mathrm{kgVS}$. Kobayashi et al. (2012) report the highest values for coffee and tea, while Naroznova et al. (2016) and Alibardi and Cossu (2016) note this for straw for pets and in vegetables. Edwiges et al. (2018) show average values in fruits and vegetables of $9.4 \% \mathrm{VS}$. From the total hemicellulose in OFMSW, unsorted wastes contribute $25 \%$ and animal wastes with less than $1 \%$.

Lignin. The lowest lignin concentrations determined in this work were for paper, fruits, and flour with $32 \mathrm{~g} / \mathrm{kgVS}$, while the highest values are for branches with $401 \mathrm{~g} / \mathrm{kgVS}$, followed by unsorted wastes with $165 \mathrm{~g} / \mathrm{kgVS}$. Naroznova et al. (2016) found that, in their analysis, the lowest content was for animal rests with $2 \% \mathrm{VS}$ and the highest for straw for domestic animals; they report the same lignin value for paper and dirty paper with $30 \mathrm{~g} / \mathrm{kgVS}$. Considering fruits, Naroznova et al. (2016) and this research agree on a lignin concentration of $4.5 \% \mathrm{VS}$ and González-Miranda et al. (2016) and Edwiges et al. (2018) with a slightly higher value of $6.4 \% \mathrm{VS}$. Of the total lignin content in OFMSW, unsorted wastes contribute $37 \%$, and paper with less than $1 \%$.

Considering that lignocellulosic compounds are not readily biodegradable, Figure 2 compares the different OFMSW fractions according to the concentration of total lignocellulosic substances and degradable carbohydrates together with protein and lipids. Degradable carbohydrates are the difference between total carbohydrates and structural carbohydrates (cellulose and hemicellulose). The lowest values for total lignocellulosic substances are for animal wastes and the highest for branches. Degradable carbohydrates are high for kitchen paper with $743 \mathrm{~g} / \mathrm{kgVS}$, followed by OFMSW and fruits with 680 and $377 \mathrm{~g} / \mathrm{kgVS}$, respectively. Figure 2 also shows no direct relationship between carbohydrates and the concentration of lignocellulosic compounds.

\subsubsection{Nutrients in OFMSW fractions}

Table 4 shows COD and Kjeldahl and ammonia nitrogen, as well as total phosphorus concentrations. The highest COD corresponds to fresh trimmings with 1,395 $\mathrm{g} / \mathrm{kgTS}$, followed by fruits, animal wastes, unsorted, and flour with values between 1,287 and 1,222 g/kgTS. From the OFMSW fractions, the lowest COD is for branches with $742 \mathrm{~g} / \mathrm{kgTS}$. Considering total COD in OFMSW, fruits and unsorted together contribute $52 \%$ of the total.

Table 4 shows that values for Kjeldahl nitrogen are highest in animal rests (protein) with $42 \mathrm{~g} / \mathrm{kgTS}$. The lowest $\mathrm{KN}$ value was found in kitchen paper. The fractions animal rests, fruits, and unsorted contribute $72 \%$ of the total Kjeldahl nitrogen.

For ammonia nitrogen in OFMSW fractions (table 4), the highest value is for animal rests with $1.7 \mathrm{~g} / \mathrm{kgTS}$ and the lowest for flour products (mainly tortilla) with $0.4 \mathrm{~g} / \mathrm{kgTS}$. All other fractions contain low NH4-N concentrations and, compared to $\mathrm{KN}$, they can be considered negligible for the purpose of methane production. Like KN in OFMSW fractions, NH4-N contribution is mainly attributed to unsorted, fruits, animal, and vegetables, with a total of $77 \%$ of the total. Campuzano and González-Martínez (2016) report similar values for Kjeldahl nitrogen for OFMSW with $18.2 \mathrm{~g} / \mathrm{kgTS}$.

OFMSW is mixed at the origin, during transportation, separation, and selection of fractions; these procedures contribute to transferring fluids among the fractions and the liquids' partial homogenization. Total phosphorus concentrations in branches are lowest with $2.4 \mathrm{~g} / \mathrm{kgTS}$, which is less than $1 \%$ of OFMSW; vegetables have the highest with $18.9 \mathrm{~g} / \mathrm{kgTS}$ (15\% of OFMSW). Fruits follow with $15.9 \mathrm{~g} / \mathrm{kgTS}$ (35\% of the total in OFMSW). In contrast, González-Miranda et al. (2016) report that unsorted has the highest value with $67.6 \%$ of the total in OFMSW and paper the lowest with $0.4 \%$.

\subsection{Methane production}

Except for branches, the curves in Figure 3 show diauxic behaviour. During the first three days, methane production increased rapidly, and then it slowed down and, after sever-

TABLE 4: COD, Kjeldahl nitrogen (KN), ammonia nitrogen (NH4-N), and total phosphorus (TP) in OFMSW fractions.

\begin{tabular}{|c|c|c|c|c|c|c|c|c|}
\hline & COD* & $\mathbf{K N}^{\star \star}$ & $\mathrm{NH}_{4}-\mathrm{N} \star \star$ & TP* & COD & $\mathbf{K N}$ & $\mathrm{NH}_{4}-\mathrm{N}$ & TP \\
\hline & \multicolumn{4}{|c|}{$\mathbf{g} / \mathbf{k g}_{\mathrm{TS}}$} & \multicolumn{4}{|c|}{$\%$ OFMSW } \\
\hline Fruits & $1287 \pm 71.4$ & $13.4 \pm 0.4$ & $1.0 \pm 0.07$ & $15.9 \pm 0.8$ & 29 & 22 & 20 & 35 \\
\hline Vegetables & $1311 \pm 90.9$ & $16.3 \pm 0.7$ & $1.3 \pm 0.08$ & $18.9 \pm 0.2$ & 10 & 9 & 11 & 15 \\
\hline Animal & $1274 \pm 45.6$ & $42.0 \pm 1.8$ & $1.7 \pm 0.12$ & $8.3 \pm 0.4$ & 12 & 30 & 18 & 8 \\
\hline Flour & $1222 \pm 58.4$ & $17.1 \pm 0.7$ & $0.4 \pm 0.03$ & $9.0 \pm 0.1$ & 4 & 4 & 1 & 3 \\
\hline Fresh trimmings & $1395 \pm 81.0$ & $16.5 \pm 1.2$ & $1.1 \pm 0.09$ & $14.0 \pm 0.4$ & 6 & 5 & 5 & 6 \\
\hline Dry leaves & $1224 \pm 72.4$ & $12.0 \pm 0.8$ & $1.2 \pm 0.10$ & $10.5 \pm 0.3$ & 8 & 6 & 8 & 7 \\
\hline Branches & $742 \pm 23.4$ & $12.8 \pm 0.6$ & $1.3 \pm 0.01$ & $2.4 \pm 0.3$ & 5 & 3 & 8 & 1 \\
\hline Kitchen paper & $1430 \pm 64.0$ & $8.5 \pm 0.4$ & $0.7 \pm 0.06$ & $10.5 \pm 0.5$ & 3 & 1 & 1 & 2 \\
\hline Unsorted & $1265 \pm 77.2$ & $15.3 \pm 0.5$ & $1.4 \pm 0.12$ & $12.9 \pm 0.6$ & 23 & 20 & 28 & 23 \\
\hline OFMSW & $1014 \pm 47.2$ & $21.1 \pm 0.5$ & $3.6 \pm 0.11$ & $13.5 \pm 0.6$ & 100 & 100 & 100 & 100 \\
\hline
\end{tabular}

* Seven replicas, ** Three replicas 


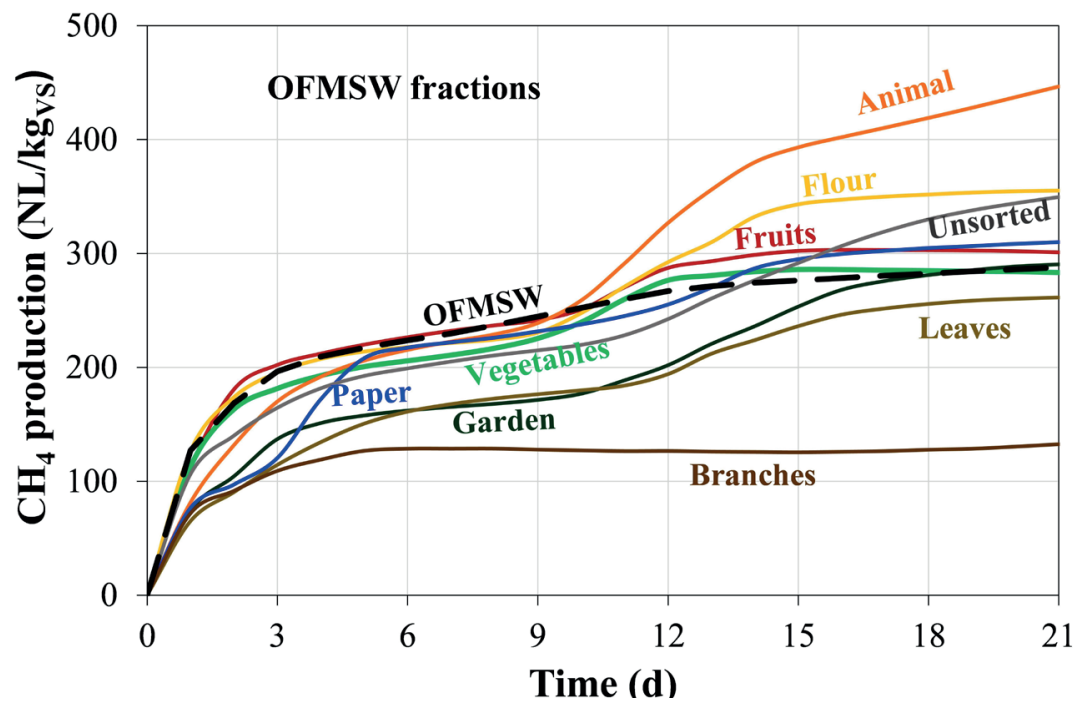

FIGURE 3: Methane production from OFMSW fractions.

al more days, it increased again to reach a point where the production became deficient until the end of the 21 days.

Animal waste and unsorted are the only fractions where low methane production continues after day 21. Branches produce methane only until day 5 . On the third day, fruits and vegetables show increasing methane production, representing more than $60 \%$ of the methane produced in 21 days, indicating that these fractions contain readily biodegradable substances. From day 4 to 9 , all fractions produced little methane, and, after day 10 , the production increased in all fractions except in branches. After day 18, the methane production receded except for animal rests and unsorted organics. The diauxic behaviour can be related to several processes during anaerobic digestion: Readily degradable substances will be transformed first, and then other substances that require longer degradation times. Analysis of the methane production curves in Figure 3 allows determining the behaviour of the previously described sequence (Campuzano and González-Martínez, 2015).

Table 5 shows methane production and concentration in the biogas after 21 days for every fraction and OFMSW. The highest methane production belongs to animal wastes with $447 \mathrm{NL} / \mathrm{kgVS}$, and the lowest belongs to branches with 133 $\mathrm{NL} / \mathrm{kgVS}$. This can be related to their composition: Animal waste has the highest protein and lipids concentrations and the lowest in lignocellulosic compounds; branches have the highest concentrations in lignocellulosic substances and the lowest in protein and lipids (see Figure 2). Labatut et al. (2011) conclude that they obtained the highest methane production from substrates rich in fat and carbohydrates and the lowest rates with lignocellulosic-rich substances. Kitchen paper absorbs fluids from other fractions, and because of this, it presents a relatively high methane production with $310 \mathrm{NL} / \mathrm{gVS}$. It can be concluded that methane production decreases with increasing concentrations of lignocellulosic substances. Xu et al. (2014) also noted that methane production was "negatively affected" when the substrate was lignin-rich and that extractable substances, such as cellulose and other compounds, are desirable because they have a "positive" effect on methane production. When Xu et al. (2014) calculated the methane production based on volatile solids, they concluded that low methane

TABLE 5: Biogas and methane production after 21 days' anaerobic digestion. Because of the characteristics of this test, only one curve was determined for every substrate.

\begin{tabular}{|c|c|c|c|c|c|}
\hline Fraction & $\underset{\%}{\mathrm{CH}_{4} \text { in biogas }}$ & $\begin{array}{c}\mathrm{CH}_{4} \text { production } \\
\mathrm{NL} / \mathrm{kg}_{\mathrm{vs}}\end{array}$ & $\begin{array}{c}\text { TBMP } \\
\text { NL/kg }\end{array}$ & $\begin{array}{c}\text { Anaerobic Biodegr. } \\
(\%)\end{array}$ & $\underset{\%}{\mathrm{CH}_{4} \text { in fraction }}$ \\
\hline Fruits & 55 & 301 & 361 & 84 & 35.1 \\
\hline Vegetables & 56 & 283 & 397 & 71 & 12.0 \\
\hline Animal waste & 62 & 447 & 641 & 70 & 11.7 \\
\hline Flour & 53 & 355 & 375 & 95 & 3.3 \\
\hline Fresh trimmings & 61 & 291 & 477 & 61 & 5.5 \\
\hline Dry leaves & 61 & 261 & 425 & 61 & 5.8 \\
\hline Branches & 64 & 133 & 599 & 22 & 1.6 \\
\hline Kitchen paper & 60 & 310 & 662 & 47 & 1.9 \\
\hline Unsorted & 58 & 350 & 489 & 72 & 22.7 \\
\hline OFMSW & 55 & 288 & 586 & 49 & 100 \\
\hline
\end{tabular}


production is related to low VS and vice versa. Fruits represent the highest contribution to total methane production in OFMSW with $35.1 \%$, followed by unsorted with $22.7 \%$. Fruits, unsorted, vegetables, and animal rests together represent $81.5 \%$ of the total methane production from OFMSW. Table 5 shows that methane concentration in the biogas for OFMSW was $55 \%$ and that animal rests, fresh trimmings, dry leaves, branches, and kitchen paper had methane concentrations above $60 \%$, indicating healthy anaerobic digestion.

Figure 4 compares experimentally determined methane production (BMP) with the theoretical one (TBMP), with and without considering the presence of lignocellulosic substances in the fractions. TMBP represents the amount of methane produced from all organic material in the sample, and it does not consider the complexity of the organic substances. Although lignocellulosic substances are considered recalcitrant to microbial degradation, several of their components, such as cellulose and hemicellulose, can be transformed under anaerobic conditions (Paul and Dutta, 2018). When these components are closely linked to lignin, they become unavailable to the microorganisms. As lignocellulosic compounds are not readily biodegradable or biodegradable, Figure 4 shows that, in all cases, TMBP has higher values than BMP.

Except for animal waste, all other fractions show that TBMP with lignocellulosic substances is higher than without them. This difference indicates that lignocellulosic substances contain biodegradable molecules, most probably hemicellulose and cellulose. Surprisingly, flour showed the highest biodegradability with $95 \%$, followed by fruits with $84 \%$ and unsorted with $72 \%$. As expected, branches has one of the highest TBMP and the lowest experimental BMP with $22 \%$ of the theoretical. Figure 4 also shows that TBMP, considering the presence of lignocellulosic substances, in all cases, has higher values than without them, but these differences are slight. It can be concluded that the presence of lignocellulosic substances in the different OFMSW fractions contributes little to methane production.

In fruits, vegetables, and unsorted, the TBMP without lignocellulosic substances and the experimental values are similar, meaning that BMP was produced from readily biodegradable substances. This can also mean that lignocellulosic substances have lower lignin concentrations or that the lignin clusters did not prevent biodegradable carbohydrates from biodegradation.

\section{CONCLUSIONS}

From Mexico City's OFMSW, nine fractions were visually identified, from which branches, dry leaves, fresh garden trimmings, unsorted wastes (primarily garden wastes), kitchen paper, and vegetable wastes together contain lignocellulosic compounds with $56 \%$ in weight. Together with fruit-waste and unsorted organics account for $60 \%$ of total methane production. Branches contain the highest concentration of lignocellulosic compounds, and it delivers the lowest methane production. Much differently, animal rests have higher protein and lipids concentrations and lower lignocellulosic substances leading to the highest level of methane production. Fibre-rich fractions in OFMSW contributed with little or no methane production. The methane production obtained in the laboratory from all fractions and OFMSW resulted in lower values than the theoretical ones.

\section{ACKNOWLED GEMENT}

This project was supported by the Mexican Centre for Innovation in Bioenergy-Cluster for Gaseous Biofuels (Centro Mexicano de Innovación en Bioenergía, Clúster en Biocombustibles Gaseosos) CONACyT project 247006. This research was performed at the Environmental Engineering Laboratory (LIA), Institute of Engineering, National University of Mexico. The graduate scholarship provided by CONACYT is acknowledged. The authors recognize the unconditional support in the laboratory and guidance through the theoretical supervision of Dr. Óscar González-Barceló.

\section{REFERENCES}

Alibardi, L., Cossu, R. 2015. Composition variability of the organic fraction of municipal solid waste and effects on hydrogen and methane production potentials. Waste Management. 36, 147-155. https://doi.org/10.1016/j.wasman.2014.11.019

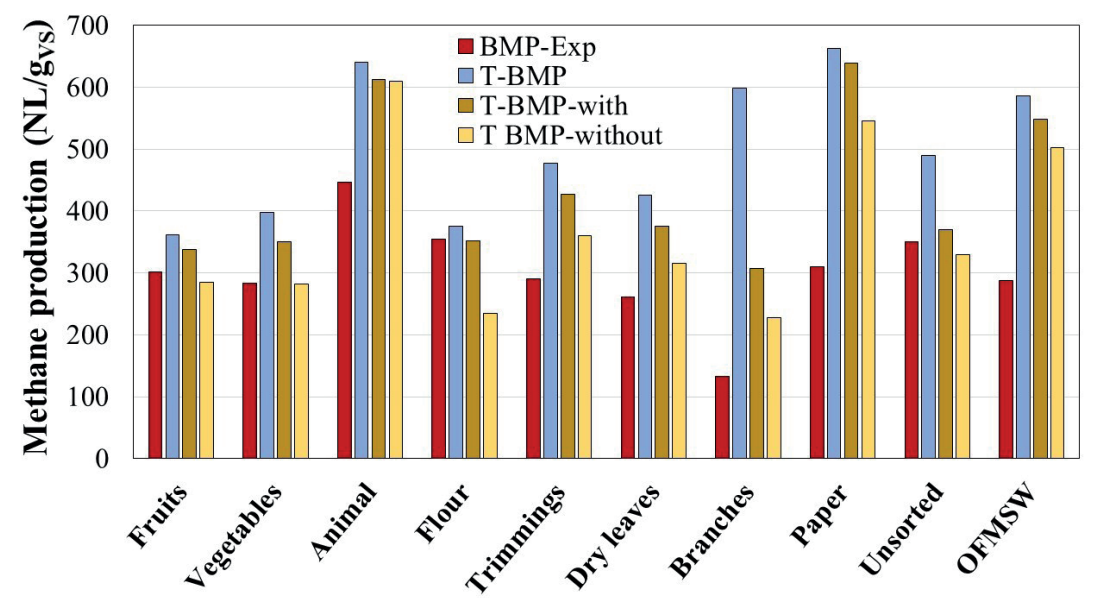

FIGURE 4: Methane production from OFMSW fractions after 21 days reaction. BMP-Exp (experimental); T-BMP (theoretical BMP); T-BMPwith (lignocellulosic substances); T-BMP-without (lignocellulosic substances). 
Alibardi, L., Cossu, R. 2016. Effects of carbohydrate, protein and lipid content of organic waste fraction and fermentation products. Waste Manage. 47 (Part A), 69-77. https://doi.org/10.1016/j.wasman.2015.07.049

AOAC, 2012. AOAC Official Methods of Analysis, 19th edition In: George Latimer, Jr. (Ed.), Association of Official Analytical Chemists, USA.

APHA. 2005. Standard Methods for the Examination of Water and Wastewater, 21st ed. American Public Health Association, American Water Works Association and Water Pollution Control Federation. Washington D.C., USA.

ASTM D5231-92. 2016. Standard Test Method for Determination of the Composition of Unprocessed Municipal Solid Waste, ASTM International, West Conshohocken, PA, 2016, https://doi.org/10.1520/ D5231-92R16

Bajpai P. 2017. Basics of Anaerobic Digestion Process. In: Anaerobic Technology in Pulp and Paper Industry. Springer Briefs in Applied Sciences and Technology. Springer, Singapore. https://doi. org/10.1007/978-981-10-4130-3_2

Banks, C.J., Chesshire, M., Stringfellow, A. 2008. A pilot-scale comparison of mesophilic and thermophilic digestion of source segregated domestic food waste. Water Sci. Technol. 58, 1475-1481. https://doi.org/10.2166/wst.2008.513

Bolzonella, D., Fatone, F., Pavan, P., Cecchi, F., 2005. Anaerobic fermentation of organic municipal solid wastes for the production of soluble organic compounds. Ind. Eng. Chem. Res. 44 (10), 3412-3418. https://doi.org/10.1021/ie048937m

Buswell, A.M., Mueller, H.F. 1952. Mechanism of Methane Fermentation. Ind. Eng. Chem. 44 (3) 550-552. https://doi.org/10.1021/ ie50507a033

Campuzano, R., González-Martínez, S. 2015. Extraction of soluble substances from organic solid municipal waste to increase methane production. Bioresour. Technol. 178, 247-253. https://doi. org/10.1016/j.biortech.2014.08.042

Campuzano, R., González-Martínez, S., 2016. Characteristics of the organic fraction of municipal solid waste and methane production: a review. Waste Manage. 54, 3-12. https://doi.org/10.1016/j.wasman.2016.05.016

Davidsson, A., Gruvberger, C., Christensen, T.H., Hansen, T.L., Jansen, J.C. 2007. Methane yield in source-sorted organic fraction of municipal solid waste. Waste Manage., 27, 406-414. https://doi. org/10.1016/j.wasman.2006.02.013

Dong, L., Zhenhong, Y., Yongming, S. 2010. Semi-dry mesophilic anaerobic digestion of water sorted organic fraction of municipal solid waste (WS-OFMSW). Bioresource Technology. 101, 2722-2728. https://doi.org/10.1016/j.biortech.2009.12.007

Edwiges, T., Frare, L., Mayer, B., Lins, L., Triolo, J.M., Flotats, X., de Mendosa Costa, M.S.S. (2018). Influence of chemical composition on biochemical methane potential of fruit and vegetable waste. Waste Manage. 71, 618-625. https://doi.org/10.1016/j.wasman.2017.05.030

Fonoll, X., Astals, S., Dosta, J., Mata-Alvarez, J. 2016. Impact of paper and cardboard suppression on OFMSW anaerobic digestion. Waste Manage. 56, 100-105. https://doi.org/10.1016/j.wasman.2016.05.023

Forster-Carneiro, T., Pérez, M., Romero, L.I. 2008. Influence of total solid and inoculum contents on performance of anaerobic reactors treating food waste. Bioresour. Technol. 99, 6994-7002. https:// doi.org/10.1016/j.biortech.2008.01.018

Ghanimeh, S., El Fadel, M., Saikaly, P. 2012. Mixing effect on thermophilic anaerobic digestion of source-sorted organic fraction of municipal solid waste. Bioresource Technology. 117, 63-71. https:// doi.org/10.1016/j.biortech.2012.02.125

Goering, H.K., Van Soest, P.J. 1970. Forage Fiber Analyses: Apparatus, Reagents, Procedures, and Some Applications. Volume 379, Agriculture handbook. U.S.D.A. Agricultural Research Service. USA.

González-Miranda, U, González-Martínez, S, Campuzano, R. 2016. Methane production from organic solid waste components. Sixth International Symposium on Energy from Biomass and Waste. Venice, Italy.

Hanc, A., Novak, P., Dvorak, M., Habart, J., Svehla, P. 2011. Composition and parameters of household bio-waste in four seasons. Waste Management. 31, 1450-1460. https://doi.org/10.1016/j.wasman.2011.02.016

Hartmann, H., Ahring, B. K. 2006. Strategies for the anaerobic digestion of the organic fraction of municipal solid waste: an overview. Water Science and Technology. 53 (8) 7-22. https://doi.org/10.2166/ wst.2006.231
Hendriks, A.T.W.M., Zeeman, G. 2009. Pretreatments to enhance the digestibility of lignocellulosic biomass. Bioresour. Technol. 100 (2009) 10-18. https://doi.org/10.1016/j.biortech.2008.05.027

Hoornweg, D., Bhada-Tata, P., Kennedy, C. 2013. Waste Production Must Peak This Century. Nature, 502 (7473) 615-617

Kaza, S., Yao, L., Bhada-Tata, P., Van Woerden, F., 2018. What a waste 2.0: A global snapshot on solid waste management to 2050. World Bank, Washington D.C., USA

Kobayashi, T., Xu, K. Q., Li, Y. Y., Inamori, Y. (2012). Evaluation of hydrogen and methane production from municipal solid wastes with different compositions of fat, protein, cellulosic materials and the other carbohydrates. Int. J. Hydrogen Energy. 37, 15711-15718. https://doi.org/10.1016/j.ijhydene.2012.05.044

Kumar, S.; Dhar, H.; Nair, V. V.; Rena; Goveni, J.; Arya, S.; Bhattacharya, J. K; Vaidya, A. N.; Akolkar, A. B. (2019). Environmental quality monitoring and impact assessment of solid waste dumpsites in high altitude subtropical regions. Journal of Environmental Management. 252, 109681. https://doi.org/10.1016/j.jenvman.2019.109681

Labatut, R.A., Angenent, N.T., Scott, N.R. 2011. Biochemical methane potential and biodegradability of complex organic substrates. Bioresour. Technol. 102, 2255-2264. https://doi.org/10.1016/j.biortech.2010.10.035

Lanzas, C., Sniffen, C.J., Seo, S., Tedeschi, L.O., Fox, D.G. 2007. A revised CNCPS feed carbohydrate fractionation scheme for formulating rations for ruminants. Animal Feed Science and Technology 136, 167-190. https://doi.org/10.1016/j.anifeedsci.2006.08.025

Manjunathaa, G.S. Chavan, D, Lakshmikanthan, P, Swamya Rajashek ar; Kumar, S. 2019. Estimation of heat generation and consequent temperature rise from nutrients like carbohydrates, proteins and fats in municipal solid waste landfills in India. Science of The Total Environment. 2019, 135610. https://doi.org/10.1016/j.scitotenv.2019.135610

Möller, K., Müller, T., 2012. Effects of anaerobic digestion on digestate nutrient availability and crop growth: A review. Engineering in Life Sciences. 12 (3), 242-257. https://doi.org/10.1002/ elsc. 201100085

Møller, H.B., Sommer, S.G., Ahring, B.K. 2004. Methane productivity of manure, straw and solid fractions of manure. Biomass Bioenergy. 26 (5) 485-495. https://doi.org/10.1016/j.biombioe.2003.08.008

Naroznova, I., Møller, J., Scheutz, C. 2016. Characterisation of the biochemical methane potential (BMP) of individual material fractions in Danish source-separated organic household waste. Waste Manage. 50, 39-48. https://doi.org/10.1016/j.wasman.2016.02.008

Nayono, S.E., Gallert, C., Winter, J. 2009. Food waste as a co-substrate in a fed-batch anaerobic biowaste digester for constant biogas supply. Water Sci. Technol. 59, 1169-1178. https://doi. org/10.2166/wst.2009.102

Nielfa, A., Cano, R., Vinot, M., Fernández, E., Fdz-Polanco, M. 2015 Anaerobic digestion modeling of the main components of organic fraction of municipal solid waste. Process Safety and Environmental Protection. 94, 180-187. https://doi.org/10.1016/j. psep.2015.02.002

Ohannessian, A., Desjardin, V., Chatain, V. Germain, P. 2008. Volatile organic silicon compounds: the most undesirable contaminants in biogases. 58 (9) 1775-1781. Water Science and Technology, https://doi: 10.2166/wst.2008.498

Papurello, D. 2019. Direct injection mass spectrometry technique for the odorant losses at $\mathrm{ppb}(\mathrm{v})$ level from nalophan ${ }^{\mathrm{TM}}$ sampling bags. International Journal of Mass Spectrometry, 436, 137-146. https:// doi.org/10.1016/j.ijms.2018.12.008

Paul, S., Dutta, A. 2018. Challenges opportunities of lignocelullosic biomass for anaerobic digestion. Resources, Conservation \& Recycling.130, 164-174. https://doi.org/10.1016/j.resconrec.2017.12.005

Rasi, S., Veijanen, V., Rintala, J. 2006. Trace compounds of biogas from different biogas production plants. Energy, 32 (8), 1375-1380. https://doi.org/10.1016/j.energy.2006.10.018

Sajeena Beevi, B., Madhu, G., Deepak Kumar Sahoo 2015. Performance and kinetic study of semi-dry thermophilic anaerobic digestion of organic fraction of municipal solid waste. Waste Management. 36 93-97. https://doi.org/10.1016/j.wasman.2014.09.024

Sniffen, C.J.,O'Connor, J.D., Van Soest, P.J., Fox, D.G., Russell, J.B. 1992 A net carbohydrate and protein system for evaluating cattle diets: II. Carbohydrate and protein availability. J. Anim. Sci. 70, 35623577. https://doi.org/10.2527/1992.70113562x

Symons, G.E., Buswell, A.M. 1933. The Methane Fermentation of Carbohydrates. J. Am. Chem. Soc. 55 (5) 2028-2036. https://doi. org/10.1021/ja01332a039 
Taherzadeh, M.J., Karimi, K. 2008. Pretreatment of lignocellulosic wastes to improve ethanol and biogas production: a review. International Journal of Molecular Science. 9, 1621-1651. https://doi. org/10.3390/ijms9091621

Teghammar, A., Yngvesson, J., Lundin, M., Taherzadeh, M.J., Horvath I.S. 2010. Pretreatment of paper tube residuals for improved biogas production. Bioresour. Technol. 101, 1206-1212. https://doi. org/10.1016/j.biortech.2009.09.029

Triolo, J.M., Sommer, S.G., Moller, H., Weisbjerg, M.R., Jiang, 2011. A new algorithm to characterize biodegradability of biomass during anaerobic digestion: Influence of lignin concentration on methane production potential. Bioresour. Technol. 102, 9395-9402. https:// doi.org/10.1016/j.biortech.2011.07.026

VALORGAS, (2010). Compositional analysis of food waste from study sites in geographically distinct regions of Europe. MTT Agrifood Research Finland. VALORGAS Project.

Van Soest, P.J. 1963. Use of detergents in the analysis of fibrous feeds. 2. A rapid method for the determination of fiber and lignin. Journal of the Association of Official Agricultural Chemists. 46 (1963) 829-835.
VDI 4630. 2016. Fermentation of Organic Materials: Characterisation of the Substrate, Sampling, Collection of Material Data, Fermentation Tests. Verein Deutscher Ingenieure. Editor Beuth Verlag, Germany.

Xu, F., Wang, Z. W., Li, Y. 2014. Predicting the methane yield of lignocellulosic biomass in mesophilic solid-state anaerobic digestion based on feedstock characteristics and process parameters. Bioresour. Technol. 173, 168-176. https://doi.org/10.1016/j.biortech.2014.09.090

Wainaina, S., Awasthi, M.K., Chen, H., Singh, E., Kumar, A., Ravindran, B., Sarsaiya, S., Awasthi, S.K., Liu, T., Duan, Y., Kumar, S., Zhang, Z. Taherzadeh, M.J., 2019. Resource Recovery and Circular Economy from Organic Solid Waste using Aerobic and Anaerobic Digestion Technologies, Bioresource Technology. 301, 122778. https://doi. org/10.1016/j.biortech.2020.122778 